\title{
PHYSIOLOGIC ACTION OF CLOSTRIDIUM WELCHII (TYPE A) TOXINS IN DOGS ${ }^{1,2,3}$
}

\author{
By PAUL C. ZAMECNIK, IRA T. NATHANSON, AND JOSEPH C. AUB \\ (From the Medical Laboratories of the Collis P. Huntington Memorial Hospital of Harvard \\ University at the Massachusetts General Hospital, Boston, Massachusetts)
}

(Received for publication September 25, 1946)

Recent work reported from this laboratory ( 1 to 7) has shown that clostridia grow and produce toxins readily in anoxic muscle in vivo, and that they are readily introduced into dog muscles during the course of traumatizing procedures. Moreover, our previous experiments have suggested that these and perhaps other bacteria may be responsible for a toxic factor contributing to shock in traumatizing wounds. Since clostridia are known to be frequent contaminants of war wounds $(8,9)$ it appeared desirable to study the physiologic action of clostridial toxins in order to determine whether these toxins could produce shock ${ }^{4}$ alone or in synergy with blood or plasma loss following trauma.

Since the action of these toxins depends on the amount used, the route of injection, and the rate of injection, we have given attention to these variables. Wright (12) has criticized studies on the pharmacologic effects of $\mathrm{Cl}$. welchii toxins in which large doses of toxin were administered rapidly, in a manner unlikely to have a parallel in the clinical disease. Study of the effects of the $\mathrm{Cl}$. welchii toxic filtrate has a particular interest in that the specific enzymatic nature of its probable principal component (the alpha toxin or lecithinase)

1 This is publication No. 630 of the Cancer Commission of Harvard University, and No. VIII of the series entitled "The Toxic Factors in Experimental Traumatic Shock."

2 The work described in this paper was done under a contract, recommended by the Committee on Medical Research, between the Office of Scientific Research and Development and the Massachusetts General Hospital.

${ }^{3}$ Grateful acknowledgment is due the Josiah Macy, Jr. Foundation for a grant for the histopathological studies.

4 We regard shock as a syndrome in which there is primarily a decline in the effective circulating blood volume, followed by a decrease in the minute volume output of the heart, an increase in peripheral vascular resistance, an eventual fall in mean arterial blood pressure and a progressive increase in tissue anoxia, resulting in death. This definition agrees with conceptions commonly held $(10,11)$. and one of its minor components (hyaluronidase) (14) are known. The lethal properties of $\mathrm{Cl}$. welchii (Type A) organisms appear to correlate well with their ability to produce the alpha toxin (15). It is therefore possible to interpret physiologic and pathologic effects of these toxins on the basis of their substrate specificities.

\section{MATERIAL AND METHODS}

Three preparations of $\mathrm{Cl}$. welchii (Type A) toxins have been used: (1) glycerol dialyzed toxic filtrate of $\mathrm{Cl}$. welchii, (2) a more purified lecithinase (alpha toxin) from $\mathrm{Cl}$. welchii, and (3) a purified $\mathrm{Cl}$. welchii hyaluronidase. 5 The glycerol dialyzed toxic filtrate has assayed from 500 to 1,760 mouse subcutaneous MLD $\left(\operatorname{LD}_{50}\right)$ per $\mathrm{ml}$. in different batches. The Lb (biological limit) varied from 17 to 43 in the various filtrates. It was made by dialyzing sterile filtrates from $\mathrm{Cl}$. welchii (Type A), strain BP6K, against glycerol for 18 hours at $4^{\circ} \mathrm{C}$. This toxic filtrate has been found by Logan (16) to contain chiefly alpha toxin, a small amount of theta toxin (accounting for fewer than 5 out of a 1,000 MLD), and 100 to 200 viscosity reducing units and 2,000 to 6,000 mucin clot prevention units of hyaluronidase activity per $\mathrm{ml}$. The $\mathrm{Cl}$. welchii hyaluronidase preparation contained no demonstrable alpha toxin, 120 van Heyningen units of theta toxin, and greater than 6,400 mucin clot prevention units of hyaluronidase activity per ml. (16). Another enzyme, a decarboxylase, which converts histidine to histamine, frequently present in strains of $\mathrm{Cl}$. welchii (17), was not found in the toxic filtrates used in these experiments.

In the majority of experiments, mongrel dogs weighing between 8 and $15 \mathrm{kgm}$. were fasted overnight, anesthetized intravenously with $30 \mathrm{mgm}$. of sodium pentobarbital per $\mathrm{kgm}$. of body weight, and were maintained as indicated under light anesthesia by subsequent small doses of the anesthetic. The trachea was exposed and cannulated so that the oxygen consumption could be recorded by a spirometer; the right carotid artery was cannulated and attached to a recording mercury manometer; and the left external jugular vein was exposed so that a catheter could be inserted to the level of the right auricle, in order to obtain mixed venous blood samples and to measure

${ }^{5}$ The first and third have been generously supplied by Dr. Milan A. Logan, and a limited quantity of purified alpha toxin was obtained through the kindness of Dr. A. M. Pappenheimer, Jr. 
venous pressure. Femoral vessels were used for obtaining arterial blood and for intravenous injections. In addition to continuous recording of blood pressure, cardiac output was determined at intervals by Fick's principle, and total peripheral vascular resistance was calculated as the quotient: blood pressure/cardiac output. Body temperature was recorded by a rectal thermometer. Heparinized blood samples were taken to measure hemoglobin concentration, hematocrit, and plasma hemoglobin (when hemolysis was present). Hemoglobins were determined on the Evelyn photoelectric colorimeter using the $540 \mathrm{mu}$ filter.

In several cases, electrocardiograms were taken, using the 3 customary leads. In one case, X-ray pictures were taken for cardiac size and configuration. Plasma volume determinations were performed by the T-1824 plasma dye dilution method (18). Plasma protein was estimated by micro-Kjeldahl nitrogen determination. Prothrombin times were done according to the method of Quick (19). All dogs were carefully autopsied and organ weights were recorded. Sections were routinely fixed in Zenker's solution. Certain tissues were fixed in $\mathbf{1 0}$ per cent formalin, and frozen sections were stained with Sudan IV for fat.

Cl. welchii toxic filtrate, which was stored in 30 per cent glycerol, was diluted $1: 3$ with physiologic saline solution before intramuscular injection, and a control experiment was done by using 10 per cent glycerol in saline. Intravenous administration was either "rapid" (the dose being given within 5 minutes) or "slow" (further diluted with saline and given by intravenous drip over a period of 2 to 3 hours). The level of free alpha toxin in the blood stream was followed by means of a modification of the egg yolk turbidimetric method of van Heyningen (20).

In tabulating results, dosages have been expressed in terms of mouse MLD per kgm. body weight. For comparison between the species, it will be recalled that the lethal dose for a mouse should be in the vicinity of 40 to 50 MLD per $\mathrm{kgm}$.

The control dogs, listed in Table $\mathrm{I}$, were treated in precisely the same way as the experimental animals, with the exception that toxic filtrate was omitted. A number of other controls were run, in which either $\mathrm{Cl}$. welchii immunized dogs were used, or in which $\mathrm{Cl}$. welchii antitoxin was mixed with the toxic filtrate prior to injection into the animal. The experiments on the effect of toxic filtrates on immunized animals will be discussed at length in a future communication (22).

\section{RESULTS}

\section{Lecithinase (alpha toxin)}

Purified Cl. welchii lecithinase (alpha toxin) was given intravenously to 2 dogs, and intramuscularly to 2 dogs. The results of intravenous administration were similar to those which will be described for the glycerol dialyzed perfringens filtrate : a dose of 40 MLD per $\mathrm{kgm}$. caused almost complete hemolysis (terminal hematocrit 5 per cent) and death in 2 hours, with small amounts of hemolyzed pleural and ascitic fluid and massive intestinal bleeding noted at postmortem examination. Intramuscular administration (60 to 90 MLD per $\mathrm{kgm}$.) resulted in only a very small amount of local edema after 5 hours, in contrast to massive swelling produced by the whole perfringens toxin. This could be due to the absence in the purified alpha toxin of some accessory factor, such as hyaluronidase.

\section{Glycerol dialyzed $\mathrm{Cl}$. welchii (Type $A$ ) toxic filtrate}

Intravenous route: Nineteen dogs were given various amounts of $\mathrm{Cl}$. welchii toxic filtrate intravenously, ranging from 6 to 800 MLD per kgm. When lethal doses (over 50 MLD per kgm.) were given, a fairly constant physiological picture resulted. Following rapid injection of large doses, the blood pressure fell precipitously to 30 to $40 \mathrm{~mm}$. $\mathrm{Hg}$ within 5 to 10 minutes, and then maintained this level for an hour or more before the terminal decline. When smaller amounts of toxic filtrate were given, or when it was given more slowly, there was no immediate response of the blood pressure, but the pressure declined more gradually.

Table I summarizes a number of changes occurring in animals in this group. It will be observed that the cardiac output, blood pressure, hemoglobin, and hematocrit show significant declines prior to death of the animal. There was, however, no significant change in the peripheral vascular resistance. A decrease in the whole blood hemoglobin and hematocrit levels provided the earliest consistent reflection of the downward trend of the animal. Figure 1 illustrates the interrelationships of these data in a typical animal.

In 2 cases, the level of free alpha toxin in the blood stream was followed by van Heyningen's method (20), while toxin was administered by slow intravenous drip. The rise in the level of free alpha toxin in the blood stream was paralleled by a rise in the plasma hemoglobin and $a$ fall in the hematocrit. In 10 out of the 12 dogs receiving a lethal dose of toxin (in which plasma hemoglobin was quantitated), the plasma was deep red, and the plasma hemoglobin reached levels between 1 and 7 grams per cent. Plasma protein concentration 
PAUL C. ZAMECNIK, IRA T. NATHANSON, AND JOSEPH C. AUB

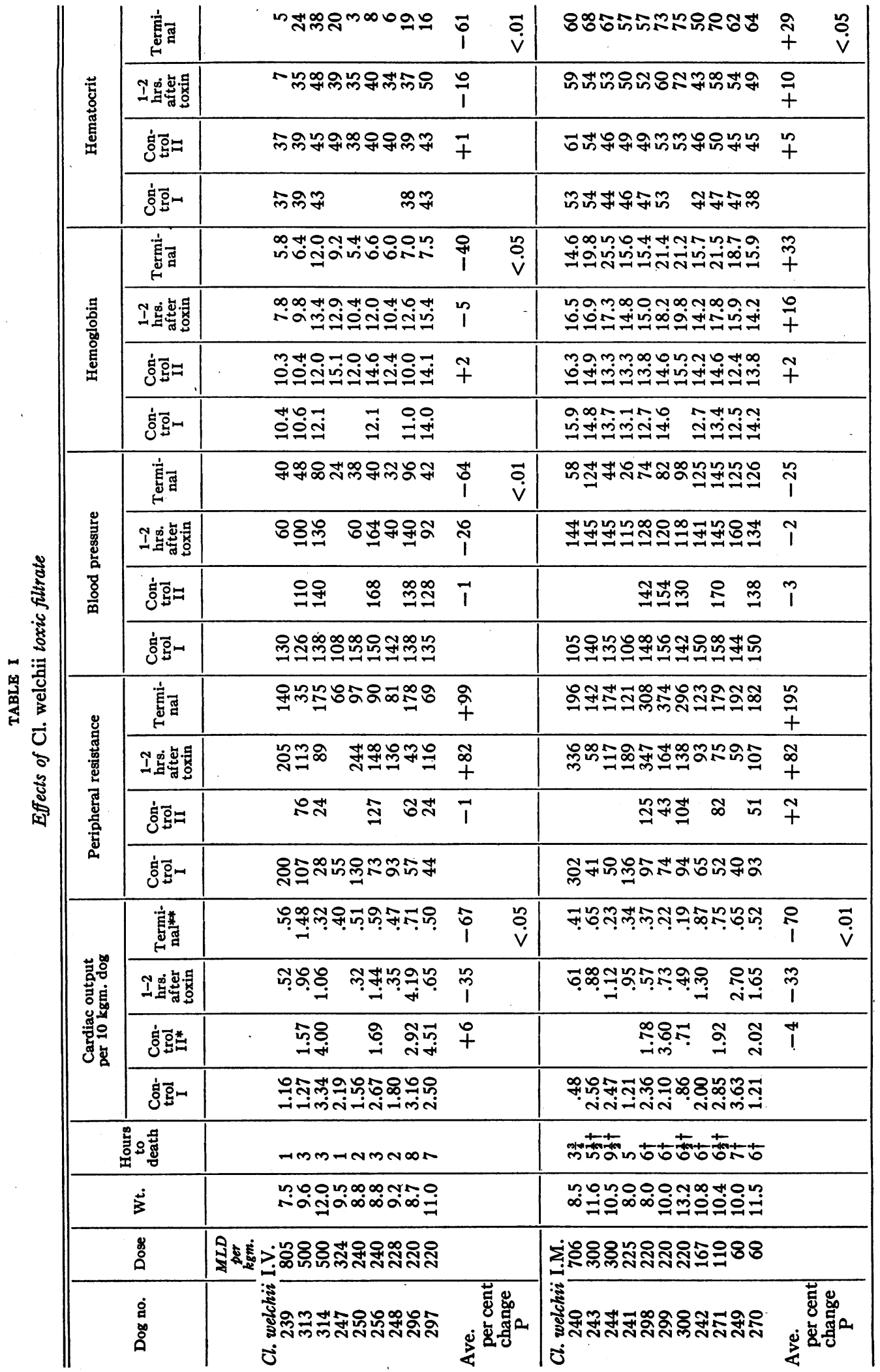


PHYSIOLOGIC ACTION OF $\mathrm{Cl}$. welchii TOXINS IN DOGS

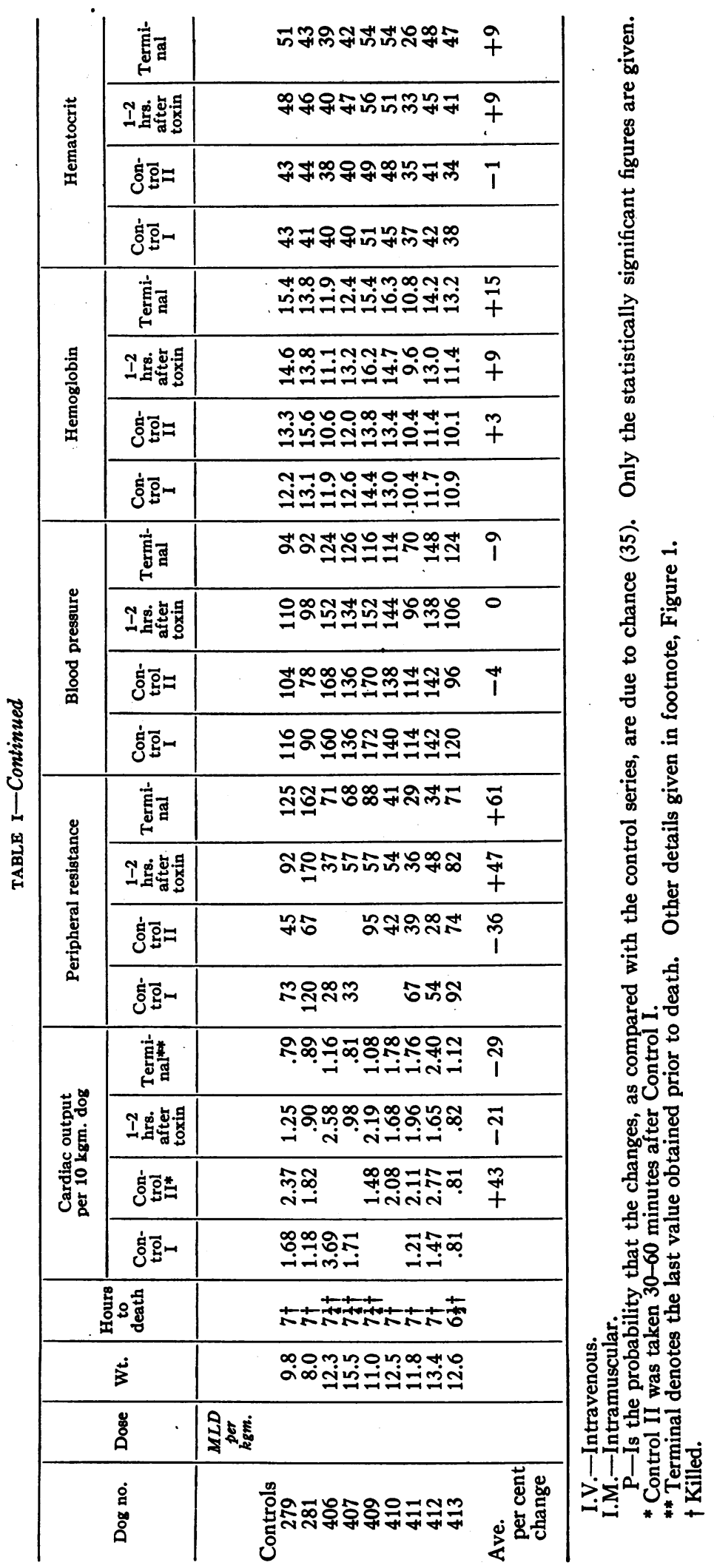




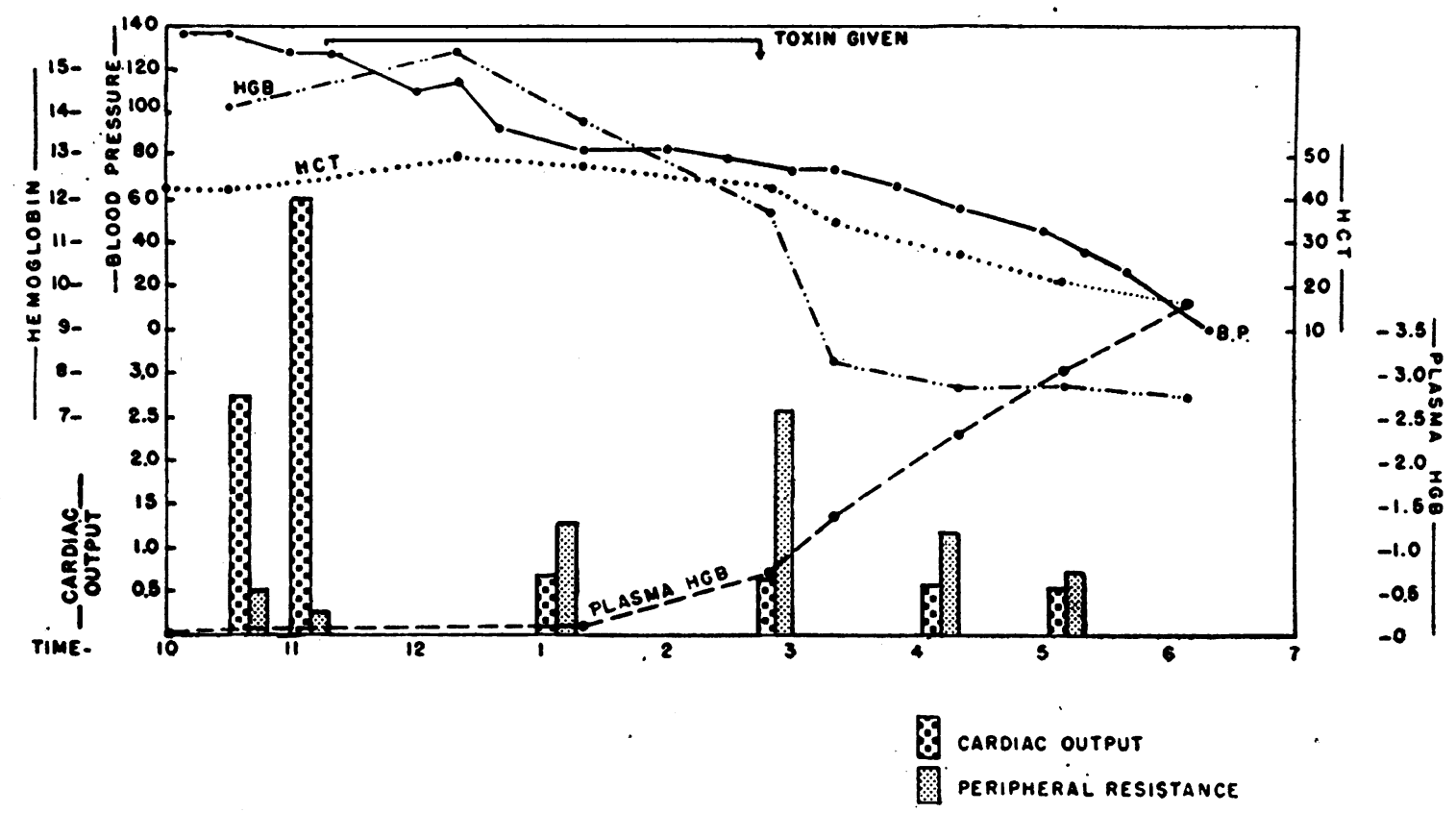

Fig. 1. Effect of $\mathrm{Cl}$. welchii Toxic Filtrate, Administered by Slow Intravenous Drip

The cardiac output is expressed in liters per minute. The relative peripheral vascular resistance is expressed in arbitrary units as the quotient: blood pressure in mm. mercury/cardiac output in liters per minute. The hemoglobin is expressed as grams per cent.

was measured in 4 such dogs, and (exclusive of hemoglobin) showed no significant change. Plasma volume dye studies were unsatisfactory due to the large amount of hemolysis. No significant change in temperature was observed.

In 4 dogs, electrocardiograms were taken at intervals, after administration of toxic filtrate, up to death 4 to 6 hours later, and failed to show evidence of myocardial damage. X-rays of the heart taken in one animal showed no change in size or configuration as a result of the toxic filtrate. The venous pressure, obtained from the region of the right auricle, was never increased.

Blood clotted poorly following venepuncture in the terminal stages after administration of toxic filtrate. The prothrombin time was tested in 4 dogs given $\mathrm{Cl}$. welchii toxic filtrate, with the following results (cf. Table II).

Intramuscular route: Twenty-six dogs were injected intramuscularly into one or both triceps surae muscles with $\mathrm{Cl}$. welchii toxic filtrate and leg volumes were made on 21 of these animals, according to a technique previously described (4). The most striking effect of the toxins was the development of massive edema, which spread out visibly from the injection site within an hour of the injection and reached a maximum 8 to 16 hours later. By measurement of the increase in volume of the thighs, an estimate of the minimal fluid loss into the limbs was made during a period of 5 to 8 hours after injection. The edema accumulating during this period amounted roughly to 1 to 3 per cent of the body weight, which therefore corresponds to a considerable fraction of the plasma volume. Hemoconcentration was a constant finding, as evidenced by an increase in hematocrit and

TABLE II

\begin{tabular}{|c|c|c|c|c|}
\hline \multirow{2}{*}{ Dog no. } & \multirow{2}{*}{ Type toxin } & \multirow{2}{*}{ Result } & \multicolumn{2}{|c|}{$\begin{array}{l}\text { Prothrombin time } \\
\text { in seconds }\end{array}$} \\
\hline & & & $\begin{array}{l}\text { Before } \\
\text { toxin }\end{array}$ & $\begin{array}{l}\text { After } \\
\text { toxin }\end{array}$ \\
\hline 234 & alpha & $\begin{array}{c}\text { survived } \\
\text { (sublethal dose) }\end{array}$ & 13 & 15 \\
\hline 235 & & died & 13 & 76 \\
\hline 238 & $\begin{array}{l}\text { glycerol } \\
\text { dial. Logan }\end{array}$ & $\begin{array}{c}\text { survived } \\
\text { (sublethal dose) }\end{array}$ & 26 & 81 \\
\hline 239 & $\begin{array}{c}\text { glycerol } \\
\text { dial. Logan }\end{array}$ & died & 15 & 74 \\
\hline
\end{tabular}


a decrease in plasma volume. A consistent fall in cardiac output was present by the sixth hour after injection. The interrelationships of these data are summarized in Tables I and III. It should be

TABLE III

Edema-producing effect of $\mathrm{Cl}$. welchii toxic filtrate following intramuscular injection

\begin{tabular}{|c|c|c|c|c|c|c|}
\hline $\begin{array}{l}\text { Dog } \\
\text { no. }\end{array}$ & Dose & $\begin{array}{c}\text { Elapsed } \\
\text { hours to } \\
\text { final } \\
\text { measure- } \\
\text { ment }\end{array}$ & $\begin{array}{c}5 \text { per cent } \\
\text { albumin } \\
\text { (B. W.** } \\
\text { injected) }\end{array}$ & $\begin{array}{c}\text { Thigh } \\
\text { edema: } \\
\text { B. W. }\end{array}$ & $\begin{array}{c}\text { Total } \\
\text { vascular } \\
\text { fluid } \\
\text { loss:† } \\
\text { B. W. }\end{array}$ & $\begin{array}{l}\text { Fate of } \\
\text { animal }\end{array}$ \\
\hline $\begin{array}{l}240 \\
243 \\
244 \\
241 \\
272 \\
273 \\
274 \\
286 \\
289 \\
290 \\
291 \\
298 \\
299 \\
300 \\
278 \\
372 \ddagger \\
242 \\
271 \\
249 \\
270 \\
246 \\
252 \\
263\end{array}$ & $\begin{array}{r}\text { MLD } \\
\text { per } \\
\text { kgm. } \\
706 \\
300 \\
300 \\
225 \\
220 \\
220 \\
220 \\
220 \\
220 \\
220 \\
220 \\
220 \\
220 \\
220 \\
187 \\
174 \\
167 \\
110 \\
60 \\
60 \\
48 \\
12 \\
4\end{array}$ & $\begin{array}{l}3 \\
5 \\
8 \frac{3}{4} \\
5 \\
6 \frac{1}{2} \\
5 \\
7 \frac{1}{2} \\
6 \frac{1}{2} \\
6 \\
6 \frac{1}{2} \\
5 \\
5 \frac{1}{2} \\
6 \\
5 \frac{1}{\frac{1}{3}} \\
6 \frac{3}{4} \\
6 \\
5 \frac{1}{2} \\
6 \frac{1}{4} \\
6 \frac{1}{2} \\
5 \frac{1}{2} \\
8 \\
5 \frac{1}{2} \\
3\end{array}$ & $\begin{array}{l}1.34 \\
3.34 \\
6.90 \\
5.55 \\
9.90 \\
4.45 \\
4.34\end{array}$ & $\begin{array}{c}\text { per cent } \\
\\
0.64 \\
1.78 \\
2.02 \\
0.80 \\
1.19 \\
2.10 \\
2.50 \\
1.53 \\
2.85 \\
2.80 \\
1.02 \\
1.69 \\
1.09 \\
1.13 \\
2.15 \\
.14 \\
1.17 \\
1.60 \\
1.94 \\
.74 \\
.89 \\
.97 \\
0\end{array}$ & $\begin{array}{c}\text { per cent } \\
\\
1.27 \\
2.90 \\
3.02 \\
1.27 \\
2.33 \\
2.94 \\
4.62 \\
3.13 \\
4.34 \\
3.94 \\
2.87 \\
3.01 \\
2.05 \\
1.67 \\
3.15 \\
0.50 \\
2.22 \\
2.49 \\
2.83 \\
1.13 \\
2.72 \\
1.78\end{array}$ & $\begin{array}{l}\text { Died* } \\
\text { Killed } \\
\text { Killed } \\
\text { Died* } \\
\text { Killed } \\
\text { Killed } \\
\text { Killed } \\
\text { Killed } \\
\text { Killed } \\
\text { Killed } \\
\text { Killed } \\
\text { Killed } \\
\text { Killed } \\
\text { Killed } \\
\text { Killed } \\
\text { Survived } \\
\text { Killed } \\
\text { Killed } \\
\text { Killed } \\
\text { Killed } \\
\text { Killed } \\
\text { Killed } \\
\text { Died* }\end{array}$ \\
\hline
\end{tabular}

* The lack of correlation between the amount of edema and death of the animal is evident here. It is possible that the toxins reached the general circulation in these instances. Among our control animals an occasional death was attributed to a combination of anesthesia and operative manipulations.

** B. W. signifies body weight.

t Due to blood loss from sampling, plus estimated vascular fluid loss as a result of edema.

$\ddagger$ Immunized animal (22).

pointed out with respect to the intramuscularly injected dogs represented in these tables, that they seldom went into shock in the limited observation period of 6 to 8 hours during which they were under anesthesia and cannulation. The blood pressure ( $c f$. Table I) showed no significant change in this group of animals. Two control dogs, injected with $300 \mathrm{MLD}$ per $\mathrm{kgm}$. of toxin mixed with 300 units of antitoxin, ${ }^{6}$ showed none of these effects. Only 5 dogs in the series showed any hemolysis, and, in all but 1 case, the hemolysis

- Lederle's polyvalent gas gangrene antitoxin. was under 0.2 gram per cent. Figure 2 illustrates the typical result of this kind of experiment.

To determine whether the toxic filtrate, when injected intramuscularly, produced general circulatory damage as well as local plasma loss, the following experiments were done:

1. Five dogs injected intramuscularly were treated by administration of 5 per cent bovine albumin $^{7}$ in amounts sufficient to maintain normal plasma volume and hematocrit values. Eight control (uninjected) dogs were maintained under similar experimental conditions. Six of these controls were also given albumin to prevent the hemoconcentration which usually occurs in dogs anesthetized with sodium pentobarbital under these conditions. The remaining 2 were untreated.

2. Two intramuscularly injected dogs were allowed to go 5 to 6 hours without treatment; at the end of this period sufficient albumin was given to replace lost plasma and blood. Before the albumin was given, tourniquets were placed around both thighs to prevent further local plasma loss.

3. In 2 dogs, casts (Castex) were placed around both legs extending from the foot pads to the groin. The toxic filtrate was injected through the casts into the triceps surae muscles. Since extensive swelling occurred above the casts (in the regions of the abdominal and gluteal muscles where the amount of swelling could not be quantitated), one was given constant albumin injection, as in (1) and the other was given a terminal albumin injection, as in (2).

The results of these experiments indicated that the decrease in cardiac output which occurred following administration of $\mathrm{Cl}$. welchii toxic filtrate intramuscularly could largely be explained by the local loss of plasma into the muscle and subcutaneous tissue in the vicinity of the injection site. Replacement of this plasma loss restored the normal cardiac output temporarily, but did not prevent further plasma loss into the damaged area. In fact, the fluid loss appeared to be somewhat increased by administration of plasma albumin, although the cardiovascular state was better maintained ( $c f$. Table III). Edema formation was not prevented by the application of casts, as it extended

7 The authors wish to express their indebtedness to Professor Edwin J. Cohn for generous supplies of purified bovine albumin. 

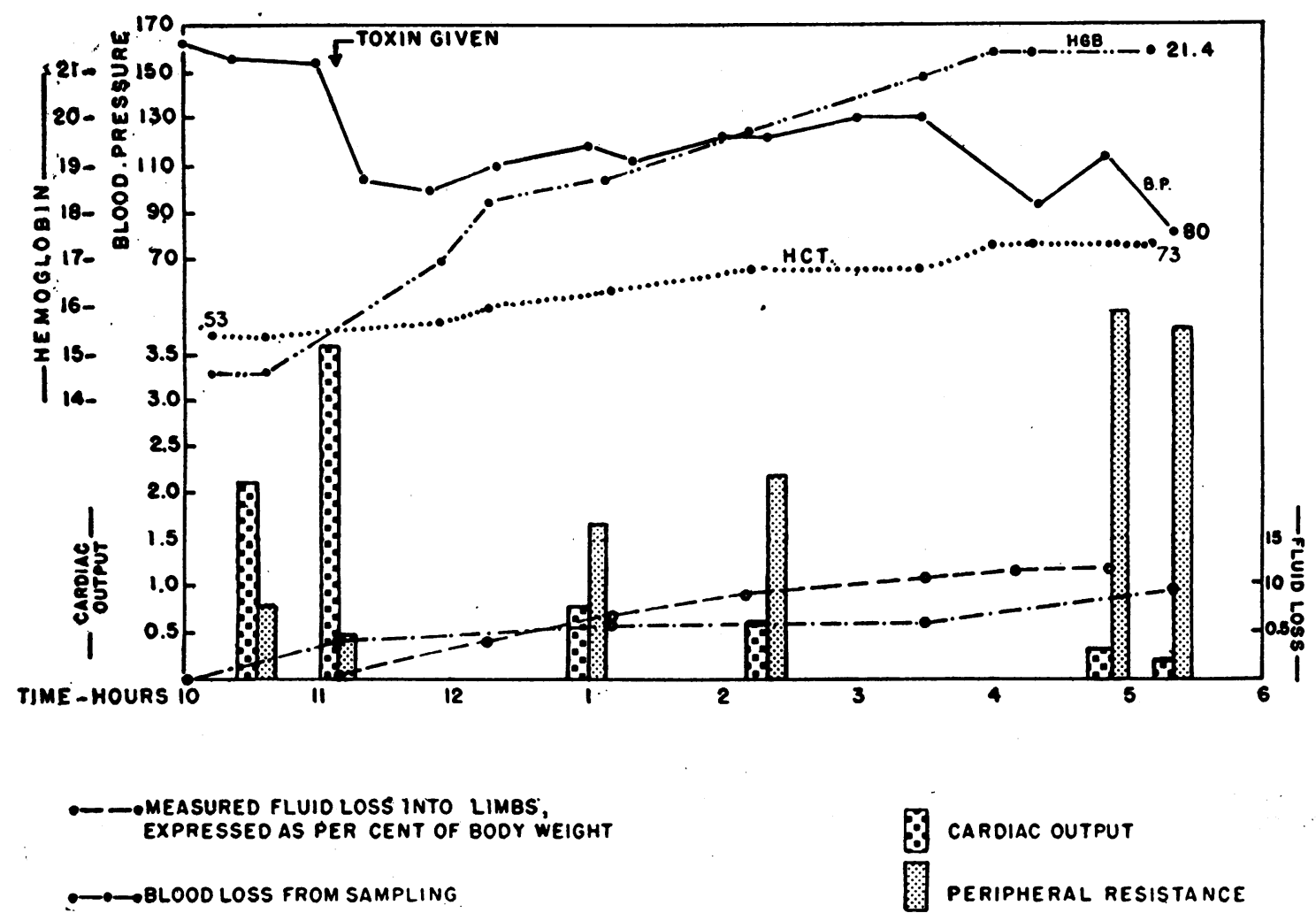

Fig. 2. Effect of $\mathrm{Cl}$. welchii Toxic Filtrate Given Intramuscularly

The blood loss is expressed as per cent of body weight. Other data are expressed as noted in Figure 1.

beyond their confines, occurring in the gluteal, perineal, and retroperitoneal regions if casts were placed about both lower extremities, and toxin was injected through the casts into the underlying musculature. In this case, in a small area immediately adjacent to the injection site, there were muscle necrosis and hemorrhage, but the casted portion of the extremity was edema free.

Three dogs injected subcutaneously with $\mathrm{Cl}$. welchii toxic filtrate presented a picture of local edema without detectable generalized effects, similar to the situation seen with the intramuscular injection.

\section{Cl. welchii hyaluronidase, intramuscular route}

Five-tenths ml. of hyaluronidase was injected into each triceps surae muscle group of an anesthetized dog. During the following 6 hours there was no evidence of generalized effects of the toxin on the cardiac output, peripheral resistance, pulse, respiration, or temperature. There was an area of edema and extravasation of blood $6 \mathrm{~cm}$. in di- ameter in the region of the injection sites, but no generalized edema of the extremities. Postmortem examination was otherwise completely negative.

\section{Pathologic findings ${ }^{8}$}

$\mathrm{Cl}$. welchii toxic filtrate given intravenously in lethal dosage to non-immunized dogs: lungs and liver showed marked congestion and edema. The weights of the lungs were significantly greater than those of control dogs (21). The small intestine, spleen, and kidneys revealed similar findings to a lesser degree. Twenty to $50 \mathrm{ml}$. of hemolyzed fluid was found in the pleural and peritoneal cavities. Where a similar dosage of toxic filtrate was given to dogs previously immunized there was no congestion of lungs, liver, or other organs. An interesting finding in such animals, however, was the presence of considerable numbers of polymorphonuclear leucocytes in the walls of the pulmonary and adrenal capillaries.

8 The authors are indebted to Dr. Benjamin Castleman for reviewing and interpreting the pathologic findings. 
Cl. welchii toxic filtrate given intramuscularly in lethal dosage to non-immunized dogs : there occurred necrosis and liquefaction of the injected muscle in the vicinity of the injection site, with extensive edema of the surrounding muscle and fascia, and a lesser degree of edema of neighboring muscles. The duodenum showed a marked capillary engorgement. The lungs, liver, adrenal, and spleen were negative. Marked cloudy swelling of the kidney was seen in one animal in this group (No. 240). An excellent, detailed description of the effects of the filtrate on muscle has been given by Robb-Smith (23).

Pathologic findings associated with intravenous injection of $\mathrm{Cl}$. welchii toxins have been reported previously (24 to 27 ). There appears to be some variation among the animal species (dogs, mice, rabbits, guinea pigs) used by the various investigators, in the sensitivity of the erythrocytes to hemolysis and in the localization of the sites of major hemorrhagic manifestations.

\section{DISCUSSION}

An attempt has been made to vary the dose, the rate, and the route of administration of $\mathrm{Cl}$. welchii toxic filtrate in order to gain a better understanding of its action on the animal. It is impossible to say what quantity of toxic filtrate might be elaborated in gas gangrene or clostridial myositis. It is therefore difficult to transfer information provided by the present experiments to the human problem. It is probable, however, that the closest simulation of clinical conditions is achieved where a relatively small dose of toxic filtrate is administered intramuscularly. Such injections have been demonstrated to evoke vascular fluid loss of considerable proportions. The additive effect of this fluid loss may be sufficient to convert into shock a traumatic condition which would not ordinarily produce this syndrome. Furthermore, the local damage to capillaries resulting from the toxins is long-lasting. If primary shock is averted by adequate therapy, clostridial toxins may introduce the possibility of delayed or secondary shock as a result of continuing fluid loss from damaged capillaries.

The action of the toxic filtrate, administered either intravenously or intramuscularly, is consistent with the damaging effect its lecithinase com- ponent might theoretically be expected to have on cell surfaces. In the case of the erythrocyte, the result is rupture of the cell wall; in the case of the vascular endothelium, the result is leakage of whole blood or plasma through a damaged membrane.

It is worth calling attention to the point that either purified $\mathrm{Cl}$. welchii alpha toxin or purified $\mathrm{Cl}$. welchii hyaluronidase in the absence of the other produced little edema during a 6-hour interval when injected intramuscularly. The edemaforming power of a filtrate containing these 2 toxins (plus a small amount of theta toxin and possibly other unknown toxins) was, however, very great during this time interval. This observation is of interest in connection with the finding of $\mathrm{McClean}$ (28) that $\mathrm{Cl}$. welchii is able to use hyaluronic acid as a metabolite.

A number of other effects of $\mathrm{Cl}$. welchii toxins (Type A) have been described and are discussed in recent reviews on the subject $(29,12)$. The observation (25) that toxic filtrates of all 4 types of $\mathrm{Cl}$. welchii liberate adenyl compounds is especially interesting and may be related to the rupture of cell membranes as a result of the action of the alpha toxin. The recent findings of Cooke et al. (9) that fat embolism may occur as a result of $\mathrm{Cl}$. welchii myositis suggest that the breakdown products of damaged cells may contribute to the generalized effect of the toxins, even though the toxins themselves may not enter into the general circulation to an appreciable degree.

MacLennan and Macfarlane $(30,31)$ have been led to consider the possibility "that the profound toxaemia of gas-gangrene is not due solely or primarily to alpha toxin." They point to the ineffectiveness of antitoxin in preventing a lethal outcome once the infection is well established and raise the question as to "whether death is due to the products of tissue breakdown rather than the direct action of bacterial toxin." While the present experiments do not conflict with this interpretation, they offer an additional explanation for the lack of effectiveness of antitoxin in well established cases of gas-gangrene, based on the following 3 points: (1) The large amount of fluid lost in clostridial myositis is not repaired by administration of antitoxin. The continuation of fluid loss from damaged blood vessels is likewise 
not prevented, since the antitoxin is unable to reverse damage which has already occurred. (2) It has been recently found in this laboratory (32) that once the $\mathrm{Cl}$. welchii lecithinase is in contact with its substrate, lecithin, it becomes difficult for antitoxin, when added to the reaction mixture, to prevent the enzymatic process from continuing. It appears that the lecithin and antitoxin compete with each other for the lecithinase. This finding offers a partial explanation for the lack of effectiveness of antitoxin when the disease is well established (i.e. when a large amount of lecithinase is in contact with its substrate). (3) It has been found possible to protect mice and dogs from a lethal intravenous dose of $\mathrm{Cl}$. welchii filtrate by means of lecithin or total lipids if these are given either in advance of or shortly after the filtrate (33). It is probable that the lecithin protects the animal (by a substrate partition effect) only from the lecithinase component of the filtrate. One may conclude that the lecithinase is in this instance the principal toxic component of the filtrate.

On the other hand, purified alpha toxin produced little edema on intramuscular injection into our dogs. This evidence suggests that collagenase (31), unknown toxins, or a synergistic effect of the combination of toxins plays important roles in the production of edema when a toxic filtrate is given intramuscularly.

An interesting teleological point is raised by the experiments of DeKruif and Bollman (34), who found that the capacity of $\mathrm{Cl}$. welchii to invade the animal body was largely dependent on its power to produce toxin. Washed $\mathrm{Cl}$. welchii bacilli or spores were infective only in very large numbers; if non-lethal quantities of toxin were added to organisms, only $1 / 10,000$ of the quantity of washed spores or bacilli was necessary to kill the animal. The alpha toxin or lecithinase appears to serve the $\mathrm{Cl}$. welchii organism by destroying the surface of animal cells, making the interior available for the nutrition of the $\mathrm{Cl}$. welchii organism.

The possibility that effects ascribed to the toxins might be due to substances used in the bacterial culture media has been ruled out by the prevention of these toxic effects both by active immunization of animals and by administration of antitoxin in advance of the toxin (22).

\section{SUMMARY}

A number of characteristics of the syndrome of traumatic shock may be produced by $\mathrm{Cl}$. welchii (Type A) toxic filtrate given by either intramuscular or intravenous route. Intravenous injection results in intravascular hemolysis, decline in cardiac output and blood pressure, increase in prothrombin time, edema and hemorrhage into the lungs and small intestine, and congestion of the liver, spleen, and kidneys.

Intramuscular or subcutaneous injection is followed by massive edema spreading from the injection site and by severe hemoconcentration. The effects of the toxic filtrate given by this route are chiefly local, and the lack of hemolysis is evidence of the inability of the alpha toxin to reach the general circulation in appreciable concentration.

Purified $\mathrm{Cl}$. welchii alpha toxin injected intramuscularly produced little edema. Purified $\mathrm{Cl}$. welchii hyaluronidase similarly had little effect on intramuscular injection. The edema-forming property of the unpurified $\mathrm{Cl}$. welchii toxic filtrate thus appears to be due to the presence of other toxins or to a synergistic effect of a combination of toxins.

Cl. welchii toxins may play an important role in certain cases of traumatic shock by aggravating fluid loss into the injured region.

The authors gratefully acknowledge the cooperation of Doctors Austin M. Brues and Alfred Pope in the early portion of this work. They are indebted to Mrs. Jean Rubin, Mrs. Barbara Barus, and Miss Lydia Brewster for valuable technical assistance.

\section{BIBLIOGRAPHY}

1. Aub, J. C., Brues, A. M., Dubos, R., Kety, S. S., Nathanson, I. T., Pope, A., and Zamecnik, P. C., Bacteria and the "toxic factor" in shock. War Med., 1944, 5, 71.

2. Nathanson, I. T., Nutt, A. L., Pope, A., Zamecnik, P. C., Aub, J. C., Brues, .A. M., and Kety, S. S., The toxic factors in experimental traumatic shock. I. Physiologic effects of muscle ligation in the dog. J. Clin. Invest., 1945, 24, 829.

3. Brues, A. M., Cohn, W. E., Kety, S. S., Nathanson, I. T., Nutt, A. L., Tibbetts, D. M., Zamecnik, P. C., and Aub, J. C., The toxic factors in experimental traumatic shock. II. Studies on electrolyte and water balance in shock. J. Clin. Invest., 1945, 24, 835.

4. Kety, S. S., Nathanson, I. T., Nutt, A. L., Pope, A., Zamecnik, P. C., Aub, J. C., and Brues. A. M.. 
The toxic factors in experimental traumatic shock. III. Shock accompanying muscle ischemia and loss of vascular fluid. J. Clin. Invest., 1945, 24, 839.

5. Aub, J. C., Brues, A. M., Kety, S. S., Nathanson, I. T., Nutt, A. L., Pope, A., and Zamecnik, P. C., The toxic factors in experimental traumatic shock. IV. The effects of the intravenous injection of the effusion from ischemic muscle. .J. Clin. Invest., 1945, 24, 845.

6. Zamecnik, P. C., Aub., J. C., Brues, A. M., Kety, S. S., Nathanson, I. T., Nutt, A. L., and Pope, A., The toxic factors in experimental traumatic shock. V. Chemical and enzymatic properties of muscle exudate. J. Clin. Invest., 1945, 24, 850.

7. Pope, A., Zamecnik, P. C., Aub, J. C., Brues, A. M., Dubos, R. J., Nathanson, I. T., and Nutt, A. L., The toxic factors in experimental traumatic shock. VI. The toxic influence of the bacterial flora, particularly Clostridium welchii, in exudates of ischemic muscle. J. Clin. Invest., 1945, 24, 856.

8. MacLennan, J. D., Anaerobic infections of war wounds in the Middle East. Lancet, 1943, 2, 63, 94, 123.

9. Cooke, W. T., Frazer, A. C., Peeney, A. L. P., Govan, A. D. T., Barling, S. G., Thomas, G., Leather, J. B., Elkes, J. J., and Scott-Mason, R. P., Clostridial infections in war wounds. Lancet, 1945, 1, 487.

10. Blalock, A., Mechanism and treatment of experimental shock. I. Shock following hemorrhage. Arch. Surg., 1927, 15, 762.

11. Wiggers, C. J., The present status of the shock problem. Physiol. Rev., 1942, 22, 74.

12. Wright, G. P., Toxic factors in wound infection. Bull. War. Med., 1942, 2, 251.

13. Macfarlane, M. G., and Knight, B. C. J. G., The biochemistry of bacterial toxins. I. The lecithinase activity of $\mathrm{Cl}$. welchii toxins. Biochem. J., 1941, 35, 884.

14. Chain, E., and Duthie, E. S., Identity of hyaluronidase and spreading factor. Brit. J. Exper. Path., 1940, 21, 324.

15. Evans, D. G., The in vitro production of $a$ toxin, $\theta$ haemolysin and hyaluronidase by strains of $\mathrm{Cl}$. welchii type $\mathrm{A}$, and the relationship of in vitro properties to virulence for guinea pigs. J. Path. and Bact., 1945, 57, 75.

16. Logan, M. A., Personal communication.

17. Gale, E. F., Production of amines by bacteria. 4. The decarboxylation of amino acids by organisms of the groups Clostridium and Proteus. Biochem. J., 1941, 35, 66.

18. Gibson, J. G., 2nd., and Evans, W. A., Jr., Clinical studies of the blood volume. I. Clinical application of a method employing the azo dye "Evans Blue" and the spectrophotometer. J. Clin. Invest., 1937, 16, 301.

19. Quick, A. J., The Hemorrhagic Diseases and the
Physiology of Hemostasis. Charles C. Thomas, Springfield, Ill., 1942, 312.

20. van Heyningen, W. E., The biochemistry of the gas gangrene toxins. I. Estimation of the $a$ toxin of Cl. welchii type A. Biochem. J., 1941, 35, 1246.

21. Aub, J. C., Zamecnik, P. C., and Nathanson, I. T., Physiologic action of Clostridium oedematiens (Novyi) toxin in dogs. J. Clin. Invest., 1947, 26, 404.

22. Nathanson, I. T., Rubin, J., Aub, J. C., and Zamecnik, P. C., Unpublished data.

23. Robb-Smith, A. H. T., Tissue changes induced by Cl. welchii type A filtrates. Lancet, 1945, 2, 362.

24. Görtzen, J., Histologische Veränderungen bei kleinen Versuchstieren nach intravenöser Einführung des Toxins des Fraenkelschen Gasbazillus ( $B$. Welchii, $B$. perfringens). Zentralbl. f. Bakt. (Abteilung 1, Originale), 1936, 138, 366.

25. Weinberg, M., and Combiesco, N., Lésions provoquées dans l'organisme animal par l'injection intraveineuse de toxine du Bacillus perfringens (hémoglobinurie, pigmentation, hémorragies, nécroses). Compt. rend. Soc. de Biol., 1930, 103, 1091.

26. Kellaway, C. H., and Trethewie, E. R., The injury of tissue cells and the liberation of pharmacologically active substances by the toxins of $\mathrm{Cl}$. welchii, types B and C. Australian J. Exper. Biol. and M. Sc., 1941, 19, 77.

27. Favata, B. V., Dowdy, A. H., Sewell, R. L., and Vincent, J. G., The pathology of experimental clostridial infections in dogs. Surg., Gynec., Obst., 1944, 79, 660.

28. McClean, D., and Hale, C. W., Studies on diffusing factors. The hyaluronidase activity of testicular extracts, bacterial culture filtrates and other agents that increase tissue permeability. Biochem. J., 1941, 35, 159.

29. Oakley, C. L., The toxins of $\mathrm{Cl}$. welchii; critical review. Bull. Hyg., 1943, 18, 781.

30. MacLennan, J. D., and Macfarlane, R. G., Toxin and antitoxin studies of gas-gangrene in man. Lancet, 1945, 2, 301.

31. Macfarlane, R. G., and MacLennan, J. D., The toxaemia of gas-gangrene. Lancet, 1945, 2, 328.

32. Zamecnik, P. C., and Lipmann, F., A study of the competition of lecithin and antitoxin for $\mathrm{Cl}$. welchii lecithinase. J. Exper. Med., 1947, 85, 395.

33. Zamecnik, P. C., Folch, J., and Brewster, L., Protection of animals against $\mathrm{Cl}$. welchii (Type A) toxin by injection of certain purified lipids. Proc. Soc. Exper. Biol. and Med., 1945, 60, 33.

34. DeKruif, P. H., and Bollman, J. L., The toxin of B. welchii, II. The mechanism of infection with B. welchii. J. Infect. Dis., 1917, 21, 588.

35. Arkin, H., and Colton, R. R., An Outline of Statistical Methods, 4th edition. De Pamphilis Press, Inc., New York, 1939, p. 127. 